\title{
On the fauna of woodlice (Crustacea: Isopoda: Oniscidea) of Sarykum cluster of Dagestan Nature Reserve (Russia)
}

\author{
Vasily A. Kolevatov ${ }^{1}$, Konstantin B. Gongalsky ${ }^{1,2}$ \\ ${ }^{1}$ Moscow State University, Leninskie Gory, 1, Moscow, 119991, Russia.E-mail: catpingus@mail.ru \\ ${ }^{2}$ A.N. Severtsov Institute of Ecology and Evolution, Russian Academy of Sciences, Leninsky \\ prospekt, 33, Moscow, 119071, Russia.E-mail: gongalsky@gmail.com \\ Vasily Kolevatov: ORCID 0000-0003-4087-9809 \\ Konstantin Gongalsky: ORCID 0000-0003-1600-8448
}

ABSTRACT. Dagestan is one of the least studied areas in the south of European part of Russia in terms of terrestrial isopods. The fauna of woodlice of Sarykum cluster of Dagestan Nature Reserve was studied in 2019. In total 6 species belonging to 4 families were collected. The fauna of woodlice of the studied cluster is similar to that of Azerbaijan and Kalmykia.

How to site this article: Kolevatov V.A., Gongalsky K.B. 2021. On the fauna of woodlice (Crustacea: Isopoda: Oniscidea) of Sarykum cluster of Dagestan Nature Reserve (Russia) // Invert. Zool. Vol.18. No.4. P.457-464. doi: 10.15298/invertzool.18.4.03

KEY WORDS: Biodiversity, Dagestan reserve, isopoda terrestria, soil fauna, woodlice.

\section{К фауне мокриц (Crustacea: Isopoda: Oniscidea) Сарыкумского кластера Дагестанского заповедника (Россия)}

\section{В.А. Колеватов ${ }^{1}$, К.Б. Гонгальский ${ }^{1,2}$}

\footnotetext{
${ }^{1}$ Московский государственный университет имени М.В. Ломоносова, Ленинские горы, 1, Москва, 119991, Россия.E-mail: catpingus@mail.ru

${ }^{2}$ Институт проблем экологии и эволющии им. А.Н. Северияова РАН, Ленинский просп., 33, Москва, 119071, Россия. E-mail: gongalsky@gmail.com
}

РЕЗЮМЕ. Дагестан - один из наименее изученных районов юга Европейской части России с точки зрения наземных изопод. В 2019 г. изучена фауна мокриц Сарыкумского кластера Дагестанского заповедника. Всего собрано 6 видов, относящихся к 4 семействам. Фауна мокриц изученного кластера сходна с таковой соседних регионов, Азербайджана и Калмыкии.

Как цитировать эту статью: Kolevatov V.A., Gongalsky K.В. 2021. On the fauna of woodlice (Crustacea: Isopoda: Oniscidea) of Sarykum cluster of Dagestan Nature Reserve (Russia) // Invert. Zool. Vol.18. No.4. P.457-464. doi: 10.15298/invertzool.18.4.03

КЛЮЧЕВЫЕ СЛОВА: биоразнообразие, Дагестанский заповедник, наземные изоподы, почвенная фауна, мокрицы. 


\section{Introduction}

The fauna of terrestrial isopods of the Republic of Dagestan has only been studied in the environs of Makhachkala city (Khisametdinova, 2012). One of the main Russian specialists in this group, E.V. Borutsky, conducted studies of woodlice in the south of the European part of Russia (Borutsky, 1951) never examining Dagestan. At the same time, the areas around Dagestan are reach in woodlice diversity. There is some information about Transcaucasia region: at least 19 species of woodlice are known from Azerbaijan (Kuznetsova, Gongalsky, 2012), however, its territory has been studied unevenly, mainly due to materials identified at different times by E.V. Borutsky and H. Schmalfuss (Schmalfuss, 1990, 1996) according to the collections of S.I. Golovach and colleagues. In recent years, there were some studies in the Lower Don and Lower Volga regions: D.D. Khisametdinova $(2007,2014)$ studied the fauna of woodlice of the Rostov Region, and K.B. Gongalsky did so in the Republic of Kalmykia (Gongalsky, 2017; Gongalsky et al., 2018). In addition, G. Kashani is actively studying the fauna of Iran's terrestrial isopods, which led to the emergence of descriptions of new species (Eshaghi et al., 2015; Kashani, Allspach, 2012). At the present time, there at least 45 species of woodlice known from Iran, many of which inhabit the southern coast of the Caspian Sea (Kashani, 2018). So, the woodlice fauna of Dagestan remains the least studied on the western coast of the Caspian Sea, and we hypothesize it to be similar to the fauna of Transcaucasia and the Lower Volga region.

Dagestan Nature Reserve is a specially protected natural area consisting of two clusters located in the Kumtorkala and Tarumovsky districts of the Republic of Dagestan, Russia. They are the Sarykum Dunes and the Kizlyar Bay. The total area of the reserve is 19061 ha, 576 ha of which fall on the Sarykum dunes (Sokolov, Syroechkovsky, 1990). The present work is devoted to survey of the fauna of the woodlice of the reserve, providing initial information on this taxon in Dagestan.

\section{Material and Methods}

The material was collected on the territory of the Sarykum Cluster in August 2019 by the first author of this study. Woodlice were caught manually on and in the soil and under shelters, and using 5 pitfall traps $(6 \mathrm{~cm}$ mouth diameter, $12 \mathrm{~cm}$ depth, filled with water to $1 / 3$ ) per site for three days. In total, 67 individuals of woodlice were collected. The animals were collected at 19 points in and around the reserve, the exact coordinates of which are provided in Table 1 . We sampled rocky outcrops of mountains, river beds, steppes, sandy dunes, and settlement areas.

The species were identified at the Laboratory for Ecological Functions of Soils of the A.N. Severtsov Institute of Ecology and Evolution RAS by the authors using special literature (Vandel, 1960; Schmölzer, 1965; Borutsky, 1975; Schmalfuss, 1990, 1996; Khisametdinova, 2014). The material is stored in the Laboratory for Ecological Functions of Soils at A.N. Severtsov Institute of Ecology and Evolution, Russian Academy of Sciences (Moscow).

\section{Results}

There are 6 species of woodlice belonging to 4 genera and 4 families recorded in the surveyed area.

Family Armadillidiidae Brandt, 1833

Genus Armadillidium Brandt, 1833

Armadillidium vulgare Latreille, 1804

A. vulgare is a Mediterranean species which is introduced to many regions of the world (Schmalfuss, 2003). It is widely distributed on the south of the European part of Russia (Kuznetsova, Gongalsky, 2012), including the environs of Makhachkala (Khisametdinova, 2012).

Records in the study area: [2] under a cobblestone $-1 \sigma^{7} ;[4]-1$; ; [5] in a pitfall trap -

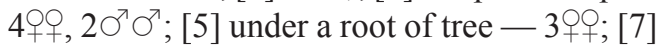
under a cobblestone - $10^{7}, 2+\%$; [8] under a tire $-2 \sigma^{7} \sigma^{7}, 19$; [9] under the root in an anthill 1 juv.; [10] under a cobblestone -1 ; ; [11] on a footpath $-10^{7}$; [11] under a stump -1 \% , 
Table 1. Localities of woodlice collection in and around the Sarykum cluster of Dagestan Nature Reserve in August, 2019.

Таблица 1. Места сбора мокриц в районе Сарыкумского кластера Дагестанского заповедника в августе 2019 г.

\begin{tabular}{|c|c|c|c|c|}
\hline No. & Lat., $\mathrm{N}$ & Long., E & Additional information & Major plant species \\
\hline [1] & $42^{\circ} 97^{\prime} 54^{\prime \prime}$ & $47^{\circ} 25^{\prime} 77^{\prime \prime}$ & $\begin{array}{l}\text { Markov Gorge, calcareous } \\
\text { rocky outcrops of a mountain } \\
\text { gap. A slightly disturbed site. }\end{array}$ & $\begin{array}{l}\text { Celtis australis } \\
\text { caucasica; Juniperus } \\
\text { communis oblonga; } \\
\text { Rhamnus pallasii; Rosa } \\
\text { gallica; Cotoneaster } \\
\text { integerrimus; } \\
\text { Scorzonera } \\
\text { biebersteinii; Ephedra } \\
\text { distachya }\end{array}$ \\
\hline [2] & $42^{\circ} 99^{\prime} 25^{\prime \prime}$ & $47^{\circ} 23^{\prime} 49^{\prime \prime}$ & $\begin{array}{l}\text { The slopes of the foothills of } \\
\text { the Narat-Tyube, calcareous } \\
\text { rocky outcrops of a mountain } \\
\text { gap. Site is disturbed by regular } \\
\text { grazing. }\end{array}$ & Same as on plot [1] \\
\hline [3] & $42^{\circ} 99^{\prime} 90^{\prime \prime}$ & $4722^{\prime} 03 ”$ & $\begin{array}{l}\text { Calcareous rocky outcrops of a } \\
\text { mountain gap. Site is disturbed } \\
\text { by regular grazing. }\end{array}$ & Same as on plot [1] \\
\hline [4] & $42^{\circ} 99^{\prime} 96^{\prime \prime}$ & $47^{\circ} 22^{\prime} 80^{\prime \prime}$ & $\begin{array}{l}\text { A dirty road in the vicinity of } \\
\text { the administration unit, a } \\
\text { severely disturbed site. }\end{array}$ & $\begin{array}{l}\text { Anisantha tectorum; } \\
\text { Hordeum murinum; } \\
\text { Euphorbia seguieriana; } \\
\text { Bromus briziformis; } \\
\text { Anthemis sterilis; } \\
\text { Artemisia scoparia }\end{array}$ \\
\hline [5] & $43^{\circ} 00^{\prime} 01^{\prime \prime}$ & $47^{\circ} 23^{\prime} 41^{\prime \prime}$ & $\begin{array}{l}\text { Saline floodplain of the } \\
\text { Shuraozen River. Site is } \\
\text { disturbed by regular grazing. }\end{array}$ & $\begin{array}{l}\text { Alhagi pseudalhagi; } \\
\text { Capparis spinosa; } \\
\text { Phragmites australis; } \\
\text { H. murinum; } \\
\text { Glycyrrhiza glabra; } \\
\text { Phelipanche arenaria; } \\
\text { Eryngium campestre }\end{array}$ \\
\hline [6] & $43^{\circ} 00^{\prime} 15^{\prime \prime}$ & $47^{\circ} 24^{\prime} 18^{\prime \prime}$ & $\begin{array}{l}\text { The bed of the dry Shuraozen } \\
\text { River }\end{array}$ & No plants \\
\hline [7] & $43^{\circ} 00^{\prime} 18^{\prime \prime}$ & $47^{\circ} 24^{\prime} 35^{\prime \prime}$ & $\begin{array}{l}\text { The bed of the dry Shuraozen } \\
\text { River }\end{array}$ & No plants \\
\hline [8] & $43^{\circ} 00^{\prime} 22^{\prime \prime}$ & $47^{\circ} 24^{\prime} 43^{\prime \prime}$ & $\begin{array}{l}\text { The bed of the dry Shuraozen } \\
\text { River }\end{array}$ & No plants \\
\hline [9] & $43^{\circ} 00^{\prime} 40^{\prime \prime}$ & $47^{\circ} 25^{\prime} 16^{\prime \prime}$ & $\begin{array}{l}\text { The bank of the dry Shuraozen } \\
\text { River }\end{array}$ & No plants \\
\hline$[10]$ & $43^{\circ} 00^{\prime} 24^{\prime \prime}$ & $47^{\circ} 24^{\prime} 50^{\prime \prime}$ & $\begin{array}{l}\text { The bed of the dry Shuraozen } \\
\text { River }\end{array}$ & No plants \\
\hline [11] & $43^{\circ} 00^{\prime} 26^{\prime \prime}$ & $47^{\circ} 23^{\prime} 76^{\prime \prime}$ & $\begin{array}{l}\text { The territory of the reserve } \\
\text { administration unit. } \\
\text { Anthropogenic site. }\end{array}$ & Cultural plantings \\
\hline
\end{tabular}


Table 1 (continued).

Таблица 1 (продолжение).

\begin{tabular}{|c|c|c|c|c|}
\hline No. & Lat., $\mathrm{N}$ & Long., E & Additional information & Major plant species \\
\hline [12] & $43^{\circ} 00^{\prime} 30^{\prime \prime}$ & $47^{\circ} 24^{\prime} 88^{\prime \prime}$ & $\begin{array}{l}\text { Living room on the territory of } \\
\text { the reserve administration unit. }\end{array}$ & No plants \\
\hline [13] & $43^{\circ} 00^{\prime} 34^{\prime \prime}$ & $47^{\circ} 23^{\prime} 85^{\prime \prime}$ & $\begin{array}{l}\text { The territory of the reserve } \\
\text { administration unit. } \\
\text { Anthropogenic site. }\end{array}$ & Cultural plantings \\
\hline [14] & $43^{\circ} 00^{\prime} 55^{\prime \prime}$ & $47^{\circ} 23^{\prime} 36^{\prime \prime}$ & $\begin{array}{l}\text { Stabilized sand near the } \\
\text { railway. }\end{array}$ & $\begin{array}{l}\text { Papaver arenarium; } \\
\text { Stipa pennata; } H . \\
\text { murinum; } \text { A. tectorum; } \\
\text { A. scoparia }\end{array}$ \\
\hline$[15]$ & $43^{\circ} 00^{\prime} 94^{\prime \prime}$ & $47^{\circ} 25^{\prime} 52^{\prime \prime}$ & $\begin{array}{l}\text { The bed of the dry Shuraozen } \\
\text { River }\end{array}$ & No plants \\
\hline$[16]$ & $43^{\circ} 00^{\prime} 99^{\prime \prime}$ & $47^{\circ} 26^{\prime} 00^{\prime \prime}$ & $\begin{array}{l}\text { Saline floodplain of the river. } \\
\text { Site is disturbed by regular } \\
\text { grazing. }\end{array}$ & Same as on plot [5] \\
\hline [17] & $43^{\circ} 00^{\prime} 09^{\prime \prime}$ & $47^{\circ} 23^{\prime} 47^{\prime \prime}$ & $\begin{array}{l}\text { Stabilized sand. Site is } \\
\text { disturbed by regular grazing. }\end{array}$ & Same as on plot [14] \\
\hline [18] & $43^{\circ} 00^{\prime} 29^{\prime \prime}$ & $47^{\circ} 23^{\prime} 75^{\prime \prime}$ & $\begin{array}{l}\text { The territory of the reserve } \\
\text { administration unit. } \\
\text { Anthropogenic site. }\end{array}$ & Cultural plantings \\
\hline [19] & $43^{\circ} 00^{\prime} 23^{\prime \prime}$ & $47^{\circ} 23^{\prime} 79^{\prime \prime}$ & $\begin{array}{l}\text { The territory of the reserve } \\
\text { administration unit. } \\
\text { Anthropogenic site. }\end{array}$ & Cultural plantings \\
\hline [20] & $43^{\circ} 00^{\prime} 11^{\prime \prime}$ & $47^{\circ} 21^{\prime} 96^{\prime \prime}$ & $\begin{array}{l}\text { Steppe. Site is disturbed by } \\
\text { regular grazing. }\end{array}$ & $\begin{array}{l}\text { Artemisia caucasica; } \text { A. } \\
\text { scoparia, Stipa } \\
\text { pulcherrima; } \text { A. } \\
\text { pseudalhagi; Alyssum } \\
\text { desertorum; Aegilops } \\
\text { cylindrica }\end{array}$ \\
\hline
\end{tabular}

$10^{7}$; [12] on the windowsill — dead 19; [13] under the concrete slab on the sand $-1+$; [15] on sandstone -2 - $+9+$ juv. in marsupium; [17] in a pitfall trap $-1+10^{7}$; [18] under a cobblestone - $10^{\top} ;$; [19] under a wooden board laying on sand - 19; [19] under a metal sheet -1 웅, $2 \sigma^{\top} \sigma^{\top} ;[20]$ under dry manure - 2 + $+9,1 \sigma^{\top}$.

Family Armadillidae Brandt, 1831 Genus Armadillo Duméril, 1816 Armadillo alievi Schmalfuss, 1990 Fig. 1A.

A. alievi was described from Azerbaijan (Schmalfuss, 1990, 2003) and recorded in northern Iran (Bakhshi et al., 2021) and in the envi- rons of Makhachkala in Dagestan (Khisametdinova, 2012). It was identified by the structure of perion-epimera I and II, telson and uropods (Schmalfuss, 1990, 1996).

Records in the study area: [1] under a cobblestone - 2o+ ; [2] under a cobblestone - 1 웅 [3] in the soil at a depth of $5 \mathrm{~cm}-4+9,1$ dead (gender is unknown); [15] on a sandstone - 1 ; [16] under a cobblestone -1 ㅇ․

Family Agnaridae Schmidt, 2003

Genus Protracheoniscus Verhoeff, 1917

Protracheoniscus major (Dollfus, 1903)

Fig. 2.

$P$. major is a species that inhabits the territory from south-east of Germany to Central Asia 


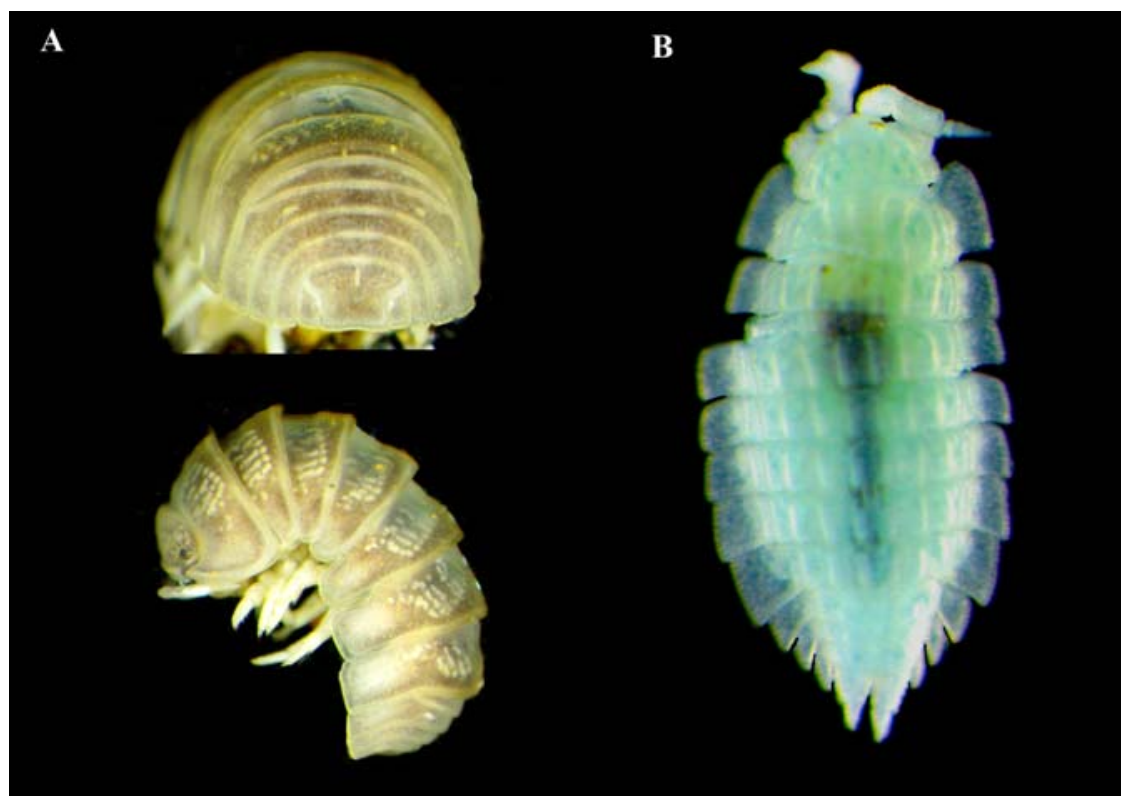

Fig. 1. General view of Armadillo alievi, $\circ, 5 \mathrm{~mm}$ (A) and Platyarthrus schoblii, $\bigcirc^{7}, 1 \mathrm{~mm}$ (B). Рис. 1. Общий вид Armadillo alievi,, , 5 мм (А) и Platyarthrus schoblii, O’, 1 мм (В).

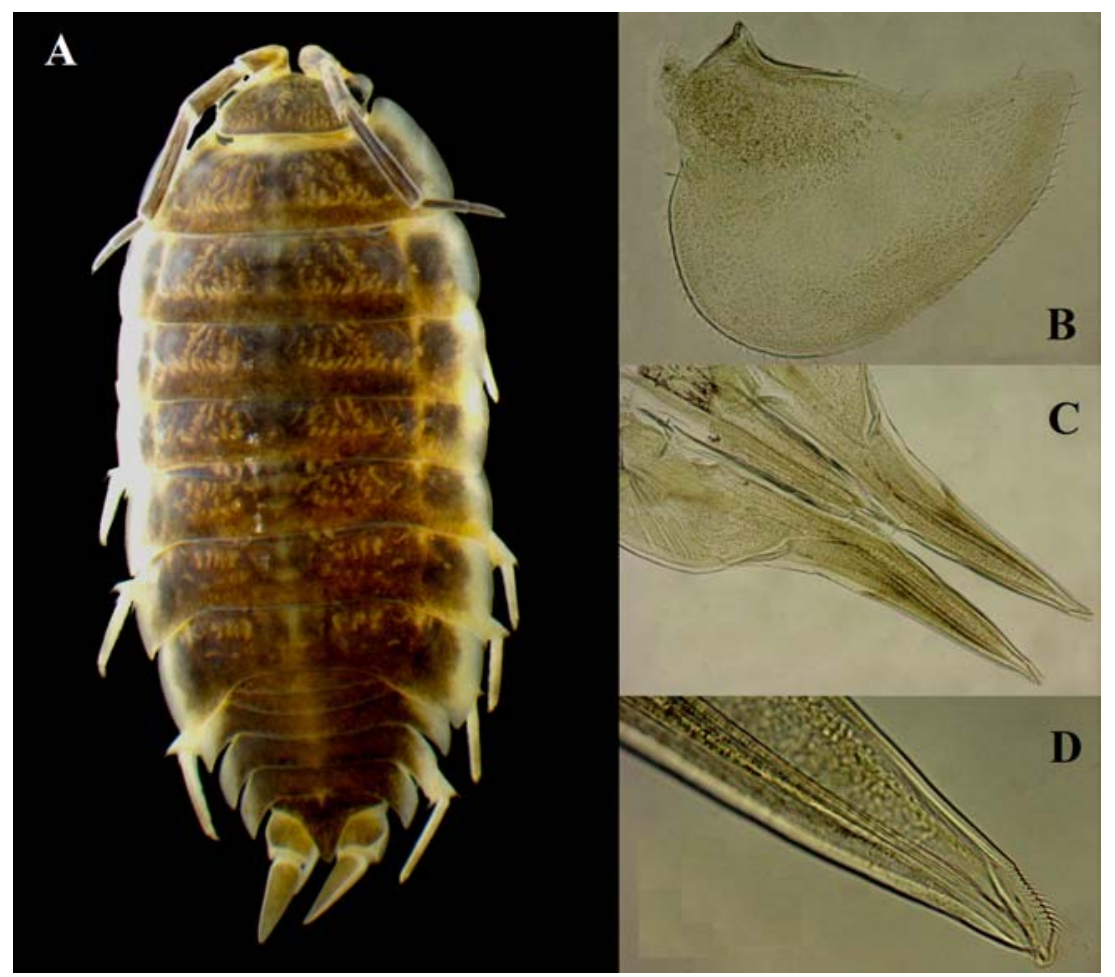

Fig. 2. Protracheoniscus major, $12 \mathrm{~mm}, \mathrm{O}^{7}$, dorsal view (A), exopod-pleopod I (B), endopod-pleopod I (C) and tip of endopod-pleopod I (D).

Рис. 2. Protracheoniscus major, 12 мм, О7, общий вид (A), экзопод плеопода I (B), эндопод плеопода I (C) и вершина эндопода плеопода I (D). 


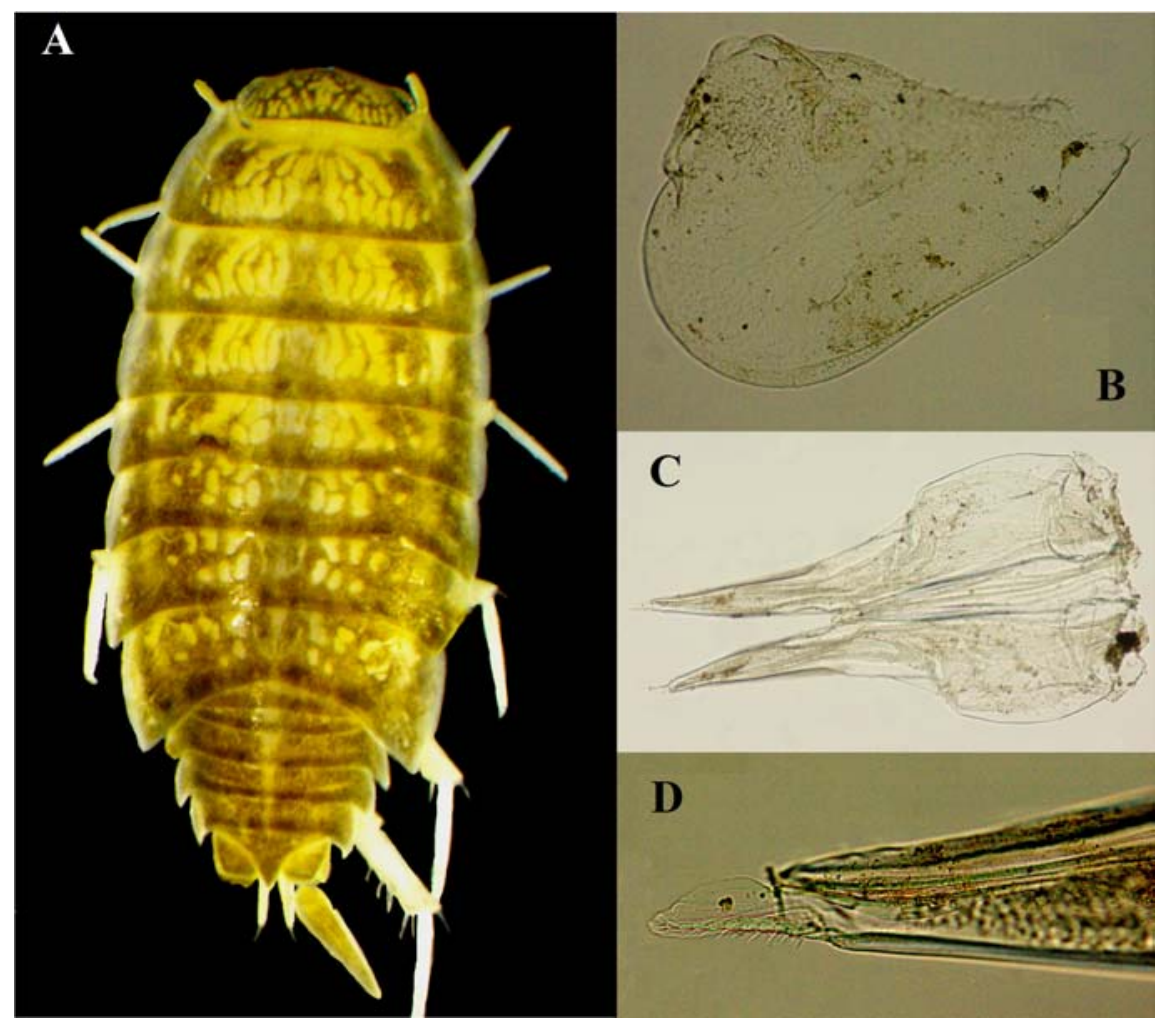

Fig. 3. Protracheoniscus nogaicus, $6 \mathrm{~mm}, \mathrm{O}^{7}$, dorsal view (A), exopod-pleopod I (B), endopod-pleopod I (C) and tip of endopod-pleopod I (D).

Рис. 3. Protracheoniscus nogaicus, 6 mm, О7, общий вид (А), экзопод плеопода I (B), эндопод плеопода I (C) и вершина эндопода плеопода I (D).

(Schmalfuss, 2003), one of the most common woodlice of the arid areas of the European part of Russia (Kuznetsova, Gongalsky, 2012). This is the first record of the species to the fauna of Dagestan.

Records in the study area: [11] under a stump - $20^{7} \sigma^{7}, 2$ 2+; [19] under a metal sheet -2 + $9,10^{\top}$.

\section{Protracheoniscus nogaicus}

Demianowicz, 1932

Fig. 3.

P. nogaicus is a species described from Moldova (Demianowicz, 1932). Recently, it was observed in the Rostov Region (Khisametdinova, 2014) and the Republic of Kalmykia
(Gongalsky et al., 2018). The record in Dagestan is both southernmost and easternmost location of this species.

Records in the study area: [6] in the soil at a depth of $10 \mathrm{~cm}-2$ 2o+; [9] under a root in the anthill -3 +o, $10^{\top}, 4$ juv.; [14] under a fallen tree -2 우.

\section{Protracheoniscus sp.}

The only individual cannot be ascribed to any other species of the genus Protracheoniscus found in the area based on morphological characters, but it cannot be identified because of the absence of males.

Records in the study area: [12] in a spiderweb - dead 1 . 
Family Platyarthridae Verhoeff, 1949

Genus Platyarthrus Brandt, 1833

Platyarthrus schoeblii Budde-Lund, 1885

Fig. 1B.

P. schoeblii is a myrmecophiles species that inhabits the Mediterranean region, coast of the Black Sea and Macaronesian islands (Schmalfuss, 2003). Previously, from the territory of the former Soviet Union it was found only from the Crimean Peninsula (reviewed in: Kuznetsova, Gongalsky, 2012). This is the first record of the species to the fauna of Dagestan. This record is thus expanding its range to the Caspian Sea coast.

Records in the study area: [9] under a root in the anthill $-10^{7}$.

\section{Discussion}

In general, the most abundant species in the catch is A. vulgare. The degree of antropogenic habitat disturbance is not affecting this species. This woodlouse is adapted to both human neighborhood and undisturbed sites. On the contrary A. alievi similar in life strategy (rolling) is sensitive to human presence and was not recorded on the territory of the administration unit. Species of the genus Protracheoniscus are equally common but live separately: $P$. major is tolerant to anthropogenic press and drought. $P$. nogaicus is smaller and more sensitive to these factors, so it occurs almost exclusively in the wettest biotope of the area, in the bed of the river. $P$. schoeblii is a small myrmecophiles woodlice that was found only once, in an anthill.

This limited material does not allow generalizing about the fauna of woodlice of Dagestan. The sandy dunes of the reserve provide unique of conditions not often occurring elsewhere in Dagestan. However, its fauna consists of common cosmopolite species and arid species, so it is similar to that of Azerbaijan (2 common species), Kalmykia (2 common species), Rostov Region (3 common species) and Iran (3 common species).

Acknowledgements. The authors are grateful to the Young Naturalists Club of Zoological
Museum of Moscow State University (head, E.A. Dunaev) and State Nature Reserve "Dagestansky" (deputy director for science, G.S. Dzhamirzoev and deputy director for Environmental Education, Z.G. Magomedova) for assistance in organizing field research. Species identifications were funded by Russian Science Foundation (grant No. 19-74-10104).

\section{References}

Bakhshi Y., Sadeghi S., Darvishnia H., Dashan M. 2021. Addition of four woodlice species (Crustacea: Isopoda) to the checklist of Iranian Oniscidea // J. Threatened Taxa. Vol.13. P.18015-18019.

Borutsky E.V. 1951. [On the fauna of terrestrial isopods of Azerbaijan] // Sbornik Trudov Zoologicheskogo Museya MGU. Vol.7. P.162-166 [in Russian].

Borutsky E.V., 1975. [New species of the genus Protrachoniscus (Isopoda, Oniscoidea)] // Zool. Zhurn. Vol.54. P.1783-1796 [in Russian].

Demianowicz A. 1932. Die Landisopoden (Isopoda terrestria) Bessarabiens. 1. Teil // Mémoires de l'Academie Polonaise des Sciences et des Lettres, Classe des Sciences mathématiques et naturelles. Série B. P.583598.

Eshaghi B., Kiabi B.H., Kashani G.M., 2015. The agnarid terrestrial isopods (Isopoda, Oniscidea, Agnaridae) of the province of Qazvin, Iran, with a description of a new species // ZooKeys. Vol.515. P.59-66.

Gongalsky K.B. 2017. The first record of the genus Desertoniscus Verhoeff, 1930 (Isopoda, Oniscidea, Agnaridae) from Europe, with the description of a new species // Zootaxa. Vol.4347. P.583-591.

Gongalsky K.B., Turbanov I.S., Medvedev D.A., Volkova J.S. 2018. Description of a new species of the genus Protracheoniscus Verhoeff, 1917 and redescription of Protracheoniscus kryszanovskii Borutzky, 1957 from the southeast of European Russia (Isopoda, Oniscidea, Agnaridae) // ZooKeys. Vol.801. P.189-205.

Kashani G.M. 2018. A preliminary checklist of terrestrial isopods (Isopoda: Oniscidea) from Iran // Iran. J. Anim. Biosystemat. Vol.14. P.123-130.

Kashani G.M., Allspach A. 2012. Redescription of Desertoniscus taschkentensis (Verhoeff, 1930) and description of Desertoniscus schmalfussi n. sp (Isopoda: Oniscidea) // Zootaxa. Vol.3154. P.40-46.

Khisametdinova D.D. 2007. [On the fauna of woodlice (Isopoda, Oniscidea) of Rostov area] // Izvestia vuzov. Severo-Kavkazskii Region. Estestvennye Nauki. Is.6. P.86-87 [in Russian].

Khisametdinova D.D. 2012. [Woodlice of the surroundings of Makhachkala city] // Materialy XIV Mezhdunarodnoi nauchnoi konferentsii "Biologicheskoe ranoobrazieKavkaza i Yugha Rossii”, posvyashchennoi 70-letiyu so dnya rozhdeniya Gayirbegha Magomedovicha Abdurakhmanova. Makhachkala. P.255-256 [in Russian]. 
Khisametdinova D.D. 2014. [Identification key of woodlice (Isopoda: Oniscidea) of the Rostov Region] // Izvestia vuzov. Severo-Kavkazskii Region. Estestvennye Nauki. Iss.2. No.180. P.72-76 [in Russian].

Kuznetsova D.M., Gongalsky K.B. 2012. Cartographic analysis of woodlice fauna of the former USSR // ZooKeys. Vol.176. P.1-11.

Schmalfuss H. 1990. Land-Isopoden aus dem KaukasusGebiet. 3. Porcellionidae, Armadillidiidae, Armadillidae // Stuttgarter Beiträge zur Naturkunde. Serie A. Bd.444. P.1-11.

Schmalfuss H. 1996. The terrestrial isopod genus Armadillo in western Asia (Oniscidea: Armadillidae), with descriptions of five new species // Stuttgarter Beiträge zur Naturkunde. Serie A. Bd.544. P.1-43.
Schmalfuss H. 2003. World catalog of terrestrial isopods (Isopoda: Oniscidea) // Stuttgarter Beiträge zur Naturkunde. Serie A. Nr.654. P.1-341.

Schmölzer K. 1965. Ordnung Isopoda (Landasseln) // Bestimmungsbücher zur Bodenfauna Europas. Lieferung 4 und 5. Berlin. $468 \mathrm{~S}$.

Sokolov V.E., Syroechkovsky E.E. (eds.). 1990. [Strict Nature Reserves of the USSR. Strict Nature Reserves of the Caucasus]. Moscow: Mysl Publ. 365 p. [In Russian]

Vandel A. 1960. Isopodes terrestres (première partie), Faune de France. Vol. 64. Paris. 416 p.

Responsible editor K.G. Mikhailov 